\title{
Book review: beyond a shadow of a diet
}

Jessica Bailes

\section{Background}

Beyond a Shadow of a Diet is an easy-to-read 338 page guidebook on how to apply the Health at Every Size ${ }^{\circ}$ (HAES ${ }^{\bullet}$ ) to treat binge eating in a psychoanalysis setting, and divided into three parts, 1. 'The Problem', 2. 'The Treatment' and 3. 'The Solution'.

Part one is an excellent introduction to diet culture and its impact on binge eating, as well as on how the therapist may be complicit in the same culture. Much of this content may also be found in the book 'Health At Every Size' by Bacon [1].

Part two outlines the principles of Intuitive Eating as described by Evelyn Trible, and gives tips to help clients adopt the approach, as well as to overcome obstacles, and manage emotions and poor body image, all through a psychoanalysis lens. Part three returns to diet culture, and the HAES(R) principles, and gives information on how clients may pursue health in a non-diet paradigm, mainly through giving references for further reading.

The authors are two social workers, who both have over 20 years' experience working in eating disorders using a psychoanalysis approach. The book benefits from their knowledge, many excellent examples from their extensive experience to illustrate how they have been treating binge eating disorder. It should be noted that their approach is not manualised, and therefore no studies have yet been done to evaluate the effectiveness of this approach.

\section{Conclusion}

Overall, this book has a good brief introduction to HAES (R), but for more in-depth information on the science of HAES ${ }^{\circ}$, readers may find the source material, such as the work by Linda Bacon and Evelyn Trible, more illuminating. Part two is where the true value of the book if found. There are so few books aimed at supporting the practioner in treating binge eating disorder, and this book has an in depth exploration of an alternative to Fairburn's CBT-E [2]. This is a welcome addition to support those who would like to use HAES (R) in their treatment psychotherapy but don't know where to start.

Correspondence: jessica@jessicabailes.com
Wesley Hospital, Ashfield, Australia

Correspondence: jessica@jessicabail
Wesley Hospital, Ashfield, Australia

(c) The Author(s). 2017 Open Access This article is distributed under the terms of the Creative Commons Attribution 4.0 International License (http://creativecommons.org/licenses/by/4.0/), which permits unrestricted use, distribution, and reproduction in any medium, provided you give appropriate credit to the original author(s) and the source, provide a link to the Creative Commons license, and indicate if changes were made. The Creative Commons Public Domain Dedication waiver (http://creativecommons.org/publicdomain/zero/1.0/) applies to the data made available in this article, unless otherwise stated.

\section{Competing interests}

The authors declare there are no competing interests.

\section{Publisher's Note}

Springer Nature remains neutral with regard to jurisdictional claims in published maps and institutional affiliations.

Received: 14 February 2017 Accepted: 13 September 2017

Published online: 27 October 2017

\section{References \\ 1. Bacon L. Health at every size: the surprising truth about your weight. 2nd ed. Dallas: BenBella Books; 2010. \\ 2. Fairburn C. Cognitive Behavioural Therapy and Eating Disorders. 1st ed. New York City: The Guilford Press; 2008.}

Submit your next manuscript to BioMed Central and we will help you at every step:

- We accept pre-submission inquiries

- Our selector tool helps you to find the most relevant journal

- We provide round the clock customer support

- Convenient online submission

- Thorough peer review

- Inclusion in PubMed and all major indexing services

- Maximum visibility for your research

Submit your manuscript at com/submit
Biomed Central 